\title{
'n Verruimde invalshoek tot die verlede? Die sosiaal-wetenskaplike benadering tot die Nuwe Testament
}

\author{
S J Joubert \\ Universiteit van Pretoria
}

\begin{abstract}
A broadened perspective to the past? The socialscientific approach to the New Testament

This paper focuses on the possibilities that the socialscientific approach holds out for the understanding of the New Testament. A review of the contributions of the sociological and the cultural anthropological approaches to the New Testament is undertaken before the social-scientific approach as a whole is evaluated. The use of social-scientific models, in particular, in the construction of the possible social contexts of the New Testament documents, is evaluated in terms of the ability of these contexts to establish 'new' systems of meaning.
\end{abstract}

Navorsers op die gebied van die Nuwe Testament is maar al te bewus van die groot kultureel-historiese afstand tussen die wêreld waarna hierdie dokumente verwys en die huidige kontekste waarbinne hulle hulleself bevind. Om dié vreemde wêreld van die Nuwe Testament minstens op 'n verantwoordbare wyse vir moderne lesers toeganklik te probeer maak, is allerlei hermeneutiese modelle en metodes oor die afgelope aantal jare ontwikkel. Eksponente van die verskillende modelle en metodes ding mee met mekaar om die aanspraak dat juis hulle die belangrikste beskikbare sleutel ter ontsluiting van die deur na dié wêreld lei, gevind het. Vir 'n lang tyd het die histories-kritiese benadering hierdie aanspraak feitlik alleen vir homself opgeëis. Maar met die opkoms van vele nuwe benaderings binne aangrensende wetenskappe het die situasie egter dramaties verander.

Nuwe-Testamentici het in toenemende mate begin kennis neem van ontwikkelings binne die vakgebiede van veral die algemene taalkunde en die sosiale weten- 
skappe, sodat dit vandag nie meer vreemd is om van die sosiologiese benadering tot die Nuwe Testament te praat nie, of van 'n antropologiese benadering, of 'n lesergeoriënteerde benadering ensovoorts.

In hierdie oorsigartikel val die fokus egter op die moontlikhede wat die sosiale wetenskappe ten opsigte van die verstaan van die Nuwe Testament bied. Die bydraes van die sosiologiese benadering sowel as die antropologiese benadering tot die Nuwe Testament, as onderafdeling van die sosiaal-wetenskaplike benadering tot hierdie dokumente, word eers kortliks aan die orde gestel voordat 'n aantal evaluerende opmerkings oor die moontlike waarde en tekortkominge van die metode in sy geheel gemaak word.

\section{DIE SOSIOLOGIESE BENADERING TOT DIE NUWE TESTAMENT}

Vanweë, onder andere, die onvermoë van die Formgeschichte om die konkrete Sitze im Leben van die Nuwe-Tetamentiese tekste bevredigend bloot te le, het verskeie ondersoekers in Noord-Amerika en Europa hulle in die vroeë sewentigerjare tot die sosiale wetenskappe, en met name dan tot die sosiologie, begin wend om modelle te vind wat hulle in staat sou stel om aan die hand van nuwe vertrekpunte en vrae dié dokumente se sosiale kontekste meer effektief te kon ontgin." Die Amerikaanse Nuwe-Testamentikus, John Gager (1975), ontleen byvoorbeeld in sy boek, Kingdom and community: The social world of early Christianity die vroeë Jesusbeweging aan die hand van Leon Festinger se model van 'kognitiewe dissonansie." Hy tipeer hulle as 'n millenialistiese beweging wat in reaksie op die wegbly van die paroesie (wat aanvanklik ten tye van Jesus se aardse optrede verwag is) steeds voortgegaan het om nuwe lede op grond van hul eskatologiese verwagtinge te werf.

'n Werk wat egter groot stukrag aan die sosiologiese ondersoek verleen het, is die nou reeds bekende monografie van Gerd Theissen (1977), getiteld Soziologie der Jesusbeweging, waarin hy die Palestynse Christendom tipeer as ' $n$ vernuwingsbeweging binne die Judaîsme bestaande uit rondreisende predikers (die s g 'Wandercharismatiker') en simpatiseerders woonagtig in sekere plaaslike gemeenskappe. Ten spyte van kritiek wat uit sekere oorde teen Theissen ingebring is, onder andere dat

\footnotetext{
- Natuurlik is die resente belangstelling in die sosiologie geen nuwigheid binne die ondersoek van die Nuwe Testament nie. Persone soos Deissman en Von Harnack het byvoorbeeld aan die begin van dié eeu reeds baanbrekerswerk in hierdie verband gedoen. Die $\mathbf{s}$ ' Chicago' skool, met persone soos $\mathrm{S}$ J Case en Shailer Matthews, het sedert 1914 met hul ondersoeke na die sosiale raamwerk van die vroeë Christendom ook baic belangrike bydraes in hierdie verband gelewer. So ook E A Judge wat in 1960 'n seminale studie oor die sosiale gedragspatrone van Christene in die eerste eeu onderneem het.
}

- Dit is wanneer groepslede tot die besef kom dat die waardestelsel waaraan hulle hulleself verbind het, om een of ander rede sy geldigheid verloor het en dan nogtans voortgaan om nuwe lede op grond van die verkeerd bewese waardestelsel te werf. 
hy geen duidelik gefundeerde teoretiese raamwerk sou aanbied aan die hand waarvan hy die Jesusbeweging sosiologies analiseer nie (aldus Gager 1979:175), slaag hy tog daarin om die Jesusbeweging op 'n vindingryke wyse as 'n sosiale fenomeen te tipeer wat te midde van bepaalde sosio-ekonomiese, politieke en kulturele prosesse tot stand gekom het, en ook eiesoortige rolle en gedragspatrone ontwikkel het.

'n Onophoudelike stroom artikels en boeke wat aan die hand van moderne sosiologiese modelle oor sosiale interaksies na verskillende aspekte van die vroeë Christendom kyk, verskyn sedert die sewentigerjare wêreldwyd op teologiese boekrakke.* Alhoewel hierdie ondersoeke in verskillende rigtings vertak wat nie altyd in waterdigte kategorieë verdeel kan word nie (vanweë onderlinge oorvleuelings), kan ons breedweg die volgende rigtings binne die huidige sosiologiese ondersoek van die Nuwe Testament onderskei:

- Ondersoeke na die sosiale organisasie en instellings van die vroeё Christendom. Aan die hand van byvoorbeeld die bekende sosioloog Max Weber se opvattinge oor charismatiese leiers (as persone wat in krisistydperke op grond van een of ander goddelike roeping 'n groep aanhangers rondom hulle eie persoon vergader), word 'n aantal studies oor charismatiese leierskap in die Nuwe Testament onderneem (vgl bv Kee 1980; Holmberg 1980, asook Malina 1984 vir 'n kritiese evaluering van Weber se model). Ondersoeke na die verskillende rolle en rolverwagtinge, die strukturering en die sosiale opset van die vroeë-Christendom word ook aan die hand van resente sosiologiese modelle gedoen (vgl bv Funk 1981; Theissen 1982; Dudley \& Hilgert 1987).

- Ondersoeke wat die wesensaard van die vroeë Christendom in terme van kontemporêre sosiologiese begrippe definieer en beskryf. Moderne teorieê oor sektarisme en kultusse (wat deur sosioloë soos Bryan Wilson en Rodney Stark ontwikkel is) word byvoorbeeld deur navorsers in hulle ondersoeke na die aard van die Jesusbeweging gebruik (vgl bv Scroggs 1975; Atwood \& Flowers 1983; White 1988). In hierdie tipe studies val die klem veral op 'n vergelyking van die vroegchristelike gemeenskappe met omringende godsdienstige bewegings in terme waarvan eersgenoemde dan op 'n bepaalde wyse getipeer word (vgl ook Theissen 1989).

\footnotetext{
- Modelle, wat die skakel tussen wetenskaplike teorieĕ en waarnemings vorm, het ten doel om eenvoudige voorstellings van objekte of gebeure te maak ten einde dit te interpreteer. In die woorde van John Elliott (1986:5): 'Models are thus conceptual vehicles for articulating, applying, testing and possibly reconstructing theories used in the analysis and interpretation of specific social data.'
} 
* Ondersoeke na die sosiale- en simboliese universums van die vroeë Christendom (met 'n eie verbale repertoire, en wat gelegitimeer word deur bepaalde simbole en rituele). Navorsingsresultate van die onderafdelings van die sosiologie, soos kennissosiologie (en in 'n minder mate sosio-linguistiek en godsdienssosiologie vgl bv Gallagher 1984; Louw 1986; Joubert 1990), word veral deur ondersoekers in hierdie verband gebruik. Een van die baanbrekers op die gebied van die kennissosiologie, te wete, Karl Mannheim, se opvattinge oor die sosiale lokaliseerbaarheid van kennis in sy verskillende verskyningsvorme, sowel as die fenomenologiese banadering van Peter Berger en Thomas Luckmann (waarvolgens hulle veronderstel dat die realiteit 'n sosiale konstruksie is) het 'n beduidende invloed op die ondersoek na die wêrelde van die vroeë Christene uitgeoefen (vgl bv Meeks 1972; Remus 1982; Rohrbaugh 1987; Joubert 1988).

- Ondersoeke na die sosiale geskiedenisse van die vroeë Christendom. Volgens 'n aantal navorsers is hierdie tipe studies streng gesproke eintlik nie deel van die sosiologiese ondersoek nie (vgl bv Gager 1979:174; Osiek 1984:4), aangesien dit nie uitsluitlik van moderne sosiologiese modelle gebruik maak nie. Resente sosiologiese modelle word hier hoogstens met inligting vanuit die argeologie en geskiedenis gekombineer. (Ten spyte van bovermelde kritiek kan hierdie tipe ondersoeke na die mening van die huidige skrywer wel onder die rubriek van die sosiologiese ondersoek geklassifiseer word juis vanweë die doelbewuste gebruikmaking van bepaalde sosiologiese modelle in die sosiale beskrywings van die vroeë Christendom.) Die ondersoeke na die sosiale geskiedenis van die vroeë Christene beoog veral om die sosiale omgewings te beskryf waarbinne die Christendom sy beslag gekry het (vgl bv Stambaugh \& Balch 1986; Meeks 1986; Kyrtatas 1987). Sekerlik die bekendste werk in dié verband is Wayne Meeks (1983) se indrukwekkende boek getiteld: The first urban Christians: The social world of the apostle Paul. Sy doelwit met hierdie werk is om vas te stel: "what it was like to become and be an ordinary Christian in the first century.' (Meeks 1983:2). In sy pogings ter beantwoording van die vraag maak hy op eklektiese wyse van uiteenlopende teorieë en modelle vanuit die sosiale wetenskappe, argeologie en geskiedeniswetenskap (sy sogenaamde 'piecemeal theory' - Meeks 1983:6) gebruik.

- Ondersoeke na die sosiaal-ekonomiese posisie van die vroeë Christene. 'n Objek van ondersoek wat soveel aandag in vakwetenskaplike tydskrifte en monografieë geniet dat dit onder 'n afsonderlike rubriek geplaas kan word, is die sosiologiese ondersoeke na die sosiaal-ekonomiese posisie van die vroeë Chris- 
tene. In sy reeds aangehaalde werk neem John Gager (1975) byvoorbeeld die standpunt in dat die eerste navolger van Jesus nie noodwendig tot die laagste sosio-ekonomiese strata binne die Jodedom behoort het nie, maar eerder tot die geledere van die sosiaal verontregtes (die $\mathrm{g}$ g am ha-arets. Aan die hand van sy analise van die betekenis van armoede in die eerste eeu kom Van Aarde (1988) tot die konklusie dat verwysings na armoede in die Nuwe Testament nie soseer op ekonomiese gebrek as op minderbevoorregtheid op sosiale gebied dui nie (so ook Malina 1987; Hollenbach 1987). Volgens Stegemann (1984) was die eerste Christene egter 'n beweging vanuit die ekonomiese armes vir die armes, terwyl Robert Smith (1980) op sy beurt weer tot die konklusie kom dat die grootste groep van die vroeë Christene tot die ekonomiese middelklasse behoort het.

- Publikasies wat die voor-en nadele van die sosiologiese werkswyse evalueer. 'n Hele aantal artikels en boeke wat aandag gee aan aspekte rakende die metodologiese verantwoording en evaluering van die sosiologiese werkwyse het oor die afgelope jare die lig gesien. Sodanige publikasies fokus veral op:

- kort oorsigte oor wat reeds deur die sosiologiese benadering vermag is,

- ondersoeke na die toepaslikheid van bepaalde sosiologiese modelle op die Nuwe Testament,

- opmerkings oor teorievorming, en

- evaluerings van die voor- en nadele van die sosiologiese werkwyse in sy geheel (vgl bv Scroggs 1980; Domeris 1988; Schmeller 1989; Kee 1989; Botha 1989).

'n Belangrike resente 'ontwikkeling' binne die sosiologiese benadering is die feit dat 'n aantal professionele sosioloë ook bydraes op die terrein van die Nuwe-Testamentiese ondersoek begin lewer. Die Duitse sosioloog Anton Mayer (1983) het byvoorbeeld onlangs 'n monografie op die gebied van die sosiologie van die Nuwe Testament die lig laat sien, terwyl Edward Tiryakian (aangehaal in L M White 1986: 249) op sy beurt Meeks se boek oor die Pauliniese Christendom geresenseer het. Rodney Stark (1986) het ook onlangs 'n kort studie oor die vroeë Christendom onderneem. 


\section{DIE ANTROPOLOGIESE BENADERING TOT DIE NUWE TESTAMENT}

\subsection{Die bydrae van Bruce Malina}

Die antropologiese benadering tot die Nuwe Testament (of ooreenkomstig die terminologie van Noord-Amerikaanse navorsers: die kultureel-antropologiese benadering) kan nie los gesien word van die baanbrekerswerke van die Amerikaanse Nuwe-Testamentikus, Bruce Malina, nie. In 1981 publiseer hy sy eerste belangrike werk in die verband, getiteld: The New Testament world: Insights from cultural anthropology. Sy basiese doelwit met die antropologiese werkwyse vat hy kortweg soos volg hierin saam: 'The purpose for using anthropological models in New Testament study is precisely to get to hear the meaning of the texts in terms of the cultural contexts in which they were originally proclaimed' (Malina 1981:v). Malina benadruk dat alle vorme van betekenis (ook taal!) aan bepaalde sosiale sisteme verbind is. In die lig hiervan is dit gebiedend noodsaaklik vir Bybellesers om kennis te dra van die betekenis van sosiale sisteme in die eerste-eeuse Mediterreense wêreld waarbinne die Nuwwe Testament sy beslag gekry het om hulle van etnosentrisme of anachronisme te vrywaar. Enige poging om sin te maak van die taal van die Nuwe Testament, en natuurlik van die waardes, gedragspatrone, rolle ensovoorts wat hierby ingebed is en waarna dit verwys, vereis egter ' $n$ kontroleerbare inter-kulturele model (Malina 1981:18). Omdat mense gewoonlik in terme van scenarios lees, poog Malina om deur middel van die antropologiese benadering vir hedendaagse lesers van scenarios te voorsien aan die hand waarvan hulle die Nuwe Testament op so 'n wyse kan lees dat 'kommunikasie' tussen hulle en die teks kan plaasvind (vgl bv Malina \& Neyrey 1988:xv).

Malina spits hom in sy navorsing veral daarop toe om die vernaamste waardes en sosiale instellings van die Mediterreense wêreld van die Nuwe Testament te beskryf. Hy identifiseer eer en skande as die sleutelwaardes van hierdie gebied in die eerste eeu n C (Malina 1981:25-50). 'Eer' hou volgens hom verband met 'n individu se aanspraak op waarde en die sosiale erkenning daarvan deur andere, terwyl 'skande' (eweneens ook 'n positiewe simbool) verband hou met 'n persoon se sensitiwiteit vir sy/haar sosiale reputasie. Eer is in die wêreld van die eerste eeu bekom deur (a) geboorte (deur byvoorbeeld in 'n aristokratiese- of priesterlike familie gebore te word); (b) dit kon deur vername persone (bv keisers) aan mense gegee word, en (c) dit kon in sosiale interaksie met andere verwerf word. Die Mediterreense samelewing was volgens Malina agonisties van aard; met ander woorde, alle vorme van interpersoonlike kontak (buite die familie en vriendekring) was gekenmerk deur 'n voortdurende kompetisie om eer te bekom en andere tot skande te bring. 
Malina omskryf die tipiese eerste-eeuse persoonlikheid as diadies van aard. In teenstelling met die hedendaagse klem op individualisme in die Westerse wêreld het persone in die Mediterreense wêreld hulleself uitsluitlik in terme van andere, veral dan die familie as primêre sosiale eenheid, verstaan. Malina (1989a:6; vgl ook 1981:53-9) stel dit as volg: '...our first century person would perceive himself as a distinctive whole set in relation to other such wholes and set within a given social and natural background; every individual is perceived as embedded in some other....' Hierdie persone was oor die algemeen anti-introspektief en geensins op psigologiese aangeleenthede ingestel nie. Mense het in die eerste eeu 'sosiaal' gefunksioneer in terme van (a) stereotipe geslagsgeoriënteerde rolle, (b) in terme van die groep waartoe hulle behoort het, en (c) in terme van hul voortdurende pogings om openbare eer te bekom (Malina 1989b:127). Die partriargaal gestruktureerde familie was, soos reeds gesê, die belangrikste groep waartoe die individu behoort het. Naas die familie het politieke instellings egter ook 'n vername rol in die Mediterreense wêreld gespeel. Trouens, volgens Malina was sake soos godsdiens en politiek te alle tye op een of ander wyse by bovermelde twee instellings ingebed. Daar was met ander woorde nie iets soos 'eksplisiete godsdiens of eksplisiete ekonomie' in die eerste eeu nie, maar eerder politieke of huishoudelike ekonomie en politieke of huishoudelike godsdiens (Malina 1986a:93).

Malina pas kultureel-antropologiese modelle en data in sy verskillende tegniese ondersoeke op die Nuwe Testament toe. Sy vernaamste werke in dié verband is:

* Christian origins and cultural anthropology (1986b), waarin hy aan die hand van die makro-interkulturele model van die Britse antropoloog Mary Douglas na die wêreld van die Nuwe Testament kyk. Aan die hand van Douglas se 'groupgrid' matriks (wat ontwerp is om gemeenskappe sosiaal te lokaliseer, asook hulle sosiale strukture, en die mate van kontrole hierbinne te analiseer), fokus Malina veral op aspekte soos rites, reinheid, persoonlike identiteit, sonde en kosmologie in sy pogings om die vroeë Christendom se sosiale ideologie- en lokaliteit te peil.

* 'n Verdere belangrike werk, wat Malina saam met Jerome Neyrey in 1988 skryf, is getiteld: Calling Jesus names: The social value of labels in Matthew. Weer eens maak die outeurs van Douglas se 'group-grid' model gebruik, sowel as van haar antropologiese navorsing oor heksery. Teorieë oor 'naamnoeming' ('labelling') en die toepassing daarvan op die verskillende name wat aan Jesus, as 'n 'afwykende persoon' ('deviant'), deur sy opponente in die Matteusevangelie toegedig word, sowel as die positiewe name wat deur Jesus se navolgers aan hom toegesè word (die sogenaamde prominence-teorie), neem egter die belangrikste plek in 
hierdie werk in.

2.2 Ander belangrike bydraes op die gebied van die antropologiese benadering tot die Nuwe Testament

Sedert Malina se aanvanklike publikasies op die gebied van die antropologie het 'n groeiende getal Nuwe-Testamentici (veral in Noord-Amerika) hulle intensief met hierdie benadering begin bemoei. Bydraes met betrekking tot die antropologiese benadering tot die Nuwe Testament verskyn veral in die volgende vakwetenskaplike tydskrifte: (a) Biblical Theology Bulletin; (b) Catholic Biblical Quarterly; en (c) Listening. 'n Uitgawe van Semeia ( $\mathrm{nr} 35,1986$ ) is ook grotendeels aan hierdie benadering gewy.

Die teoretiese begronding van die antropologiese werkwyse geniet aanvanklik heelwat aandag onder navorsers (vgl Leland White 1986; Elliott 1986). 'n Groot groep voorstanders van hierdie benadering verkies egter om die antropologiese benadering met ander dissiplines vanuit die sosiaal-wetenskappe te kombineer en eerder van 'n sosiaal-wetenskaplike benadering te praat; 'n tendens wat Malina self ook in latere publikasies volg. (Tog maak die studies wat hieronder bespreek word byna uitsluitlik van antropologiese modelle in hul ondersoeke van die wêreld[e] van die Nuwe Testament gebruik.) Mary Douglas se 'group-grid' model, soos aangepas deur Malina, het in dié verband veral groot byval by ondersoekers gevind. Leland White (1986) analiseer byvoorbeeld die 'geregtigheid-kodes' in die bergpredikasie (Matt 5-7) aan die hand van hierdie model en kom tot die konklusie dat die gemeenskap aan wie hierdie skrywe oorsponklik gerig is, 'n leierlose en sosiaal veragte gemeenskap van gelykes was. Die bergpredikasie bied juis nou vir die groep 'n alternatiewe wêreld waar God (onder andere) eer aan hulle as swakkes bewys indien hulle op hulle beurt weer geregtigheid aan andere (ook diegene wat hulle minag en hul eer uitdaag) bewys. Jerome Neyrey (1988a) maak ook ruimskoots van Douglas se bevindinge gebruik in 'n belangwekkende monografie getiteld: $A n$ ideology of revolt: John's Christology in social-science perspective. Laasgenoemde werk fokus op die Christologiese uitsprake in die Johannesevangelie waar verwys word na Christus se gelykheid aan God (Joh 5:18; 10:31-3). In die eerste gedeelte van die boek fokus Neyrey op wat hy noem 'tradisionele' eksegetiese aangeleenthede wat betrekking het op hierdie uitsprake. In deel twee van die boek maak hy veral van die 'group-grid' matriks gebruik ter verklaring van veral die 'vlees/gees'dichotomie, sowel as ter verduideliking van die kulturele implikasies van die term 'gees' (volgens hom 'n simbool vir 'n strategie van opstand teen die sinagoge) in die Johannesevangelie. 
'n Navorser wat ruimskoots van inligting vanuit die kulturele en mediese antropologie gebruik maak in sy analises van siekte, genesing en genesers (veral) in die Sinoptiese Evangelies, is John Pilch (1985, 1986, 1988a, 1989). Aan die hand van sy ondersoeke na die verskynsel van siekte en die hantering daarvan in die eerste eeu, beklemtoon hy die noodsaak om hierdie sake vanuit die waardesisteme en semantiese netwerke van die Mediterreense wêreld te beskou en nie vanuit moderne biomediese modelle nie (vgl bv Pilch 1988:60-1). Pilch wys onder andere daarop dat die menslike liggaam in die eerste eeu in drie simboliese sones van organe en gedragspatrone verdeel is, te wete (a) die hart/oë sone waarmee die mens data versamel en dink, (b) die mond/oor sone waarmee die individu ook data versamel, maar veral kommunikeer, en (c) die hand/voet sone waarmee die mens beweeg en handel (Pilch 1989:283). 'n Persoon in die Nuwe-Testamentiese tyd is as gesond geklassifiseer indien hierdie drie sones van die liggaam in harmonie met mekaar gefunksioneer het.

'n Monografie waarby ook kortliks stilgestaan word, is dié van Halvor Moxnes (1988a) (waarskynlik die enigste Nuwe-Testamentikus op Europese bodem wat hom intensief met die antropologiese benadering bemoei) getiteld: The economy of the kingdom: Social conflict and economic relations in Luke's gospel. Moxnes, wat in hierdie studie daarin slaag om histories-kritiese navorsing met antropologiese modelle te kombineer, fokus veral op die sosiale wêreld van die Lukasevangelie, en met name op die rol wat ekonomie in die eerste-eeuse wêreld gespeel het. Volgens hom verwys Lukas dikwels in sy evangelie na Jesus se optredes in die klein landelike dorpies in Galilea, Samaria en Judea. Die inwoners van hierdie dorpies was grotendeels landbouers met 'n sogenaamde 'limited good' opvatting. (In navolging van die antropoloog $\mathrm{G}$ Forster gebruik hy hierdie term ter verwysing na die voortdurende tekort aan alle noodsaaklike middele en waardes in die lewe.) Hierdie boeregemeenskappe was bloot op ekonomiese oorlewing ingestel, en het alle beskikbare lewensmiddele gewoonlik onder lede van hul gemeenskap verdeel. Teenoor dié gemeenskappe (wat ongeveer 95\% van Palestina se bevolking beslaan het) staan 'n klein groepie rykes wat toegang tot al die mag en welvaart gehad het (die sogenaamde stedelike elite) met totaal ander ekonomiese opvattinge, en wat eersgenoemde groepe gewoonlik geëksploiteer het. Lukas oefen ernstige kritiek op die rykes se waardesisteme en optrede uit. Hy verwag nou van sy lesers, wat waarskynlik tot die plattelandse en stedelike non-elite behoort het, om hul besittings onder mekaar te verdeel, en om (in skrille kontras met die ekonomiese 'patron-client' sisteme van hul dag) materiële hulp aan andere (ook buitestaanders) te bewys sonder om enige vorm van kompensasie te verlang (vgl ook Moxnes 1988b). 


\section{DIE VOOR- EN NADELE VAN 'N SOSIAAL-WETENSKAPLIKE BENA-} DERING TOT DIE NUWE TESTAMENT

Soos wat dit uit bogenoemde bespreking blyk, het die vermelde ondersoeke tot op hede 'n positiewe bydrae tot die Nuwe-Testamentiese wetenskap gelewer. Terwyl die sosiologiese benadering byna uitsluitlik van metodes gebruik maak wat vir die bestudering van moderne gemeenskappe ontwikkel is, poog die kulturele antropologie weer om, spesifiek dan in die geval van ondersoeke na die Mediterreense wêreld van die eerste eeu, aan die hand van die beskikbare gegewens te probeer vasstel hoe hierdie sosiale sisteme gefunksioneer het, ensovoorts. Laasgenoemde werkwyse, soos dit tans op die Nuwe Testament toegepas word, neem die sosiale sisteme waarna hierdie tekste verwys, ernstig op en veronderstel dat legitieme lesings hiervan slegs kan plaasvind indien pasgenoemde aspekte, wat uiteraard in die tekste geënkkodeer is, grondig verdiskonteer word.

Die sosiologie bied aan die hand van moderne modelle van sosiale interaksie (werkende) hipoteses met betrekking tot verskillende aspekte van hierdie prosesse aan Nuwe-Testamentici. Volgens die meerderheid sosioloë bestaan daar (natuurlik op 'n hoë vlak van abstraksie) 'n paar basiese modelle aan die hand waarvan samelewingsverbande en die sosiale verhoudings hierbinne geanaliseer word (vgl bv Turner 1982). Hierdie modelle is: (a) die konflik-model, wat sosiale sisteme beskou in terme van die uiteenlopende doelwitte van groepe wat in voortdurende konflik met mekaar gewikkel is ter realisering van hulle eie belange (vgl ook Malina 1988); (b) Die struktureel-funksionele model, in terme waarvan bepaalde samelewings as 'n geïntegreerde geheel beskou word met dieselfde waardes en norme (vgl ook Pilch 1988 b); (c) Die simboliese model, in terme waarvan groepsgedrag rondom spesifieke simboliese betekenisse en verwagtinge georganiseer word wat aan bepaalde objekte gekoppel word (vgl ook Neyrey 1988b). In enige sosiologiese lesing van die Nuwe Testament, wat die dekodering van die sosiale kodes in die tekste behels, moet hierdie modelle (en gepaardgaande sosiologiese teorieë) egter getoets word teen oorhaastige analogieë of aanduidings van allerlei gemeenskaplike delers tussen kontemporêre gemeenskappe en vroeg-christelike groepe. Aan die ander kant bied die sosiologie tog aan ons 'n rykdom van inligting oor interpersoonlike gedrag wat deur streng metodologiese navorsing bekom is, en wat, indien dit gekontroleerd op die Nuwe Testament toegepas word, nuwe inligting met betrekking tot die sosiale dinamika van die vroeë Christendom beskikbaar kan stel.

In plaas daarvan dat Nuwe-Testamentici egter moet kies tussen bogenoemde twee sosiale dissiplines, is dit meer sinvol, veral met die oog op die beperkte hoeveelheid navorsingsmateriaal wat beskikbaar is, om eerder inligting vanuit sowel die sosiologie as die kulturele antropologie in ondersoeke te kombineer. 'n Sodanige 
sosiaal-wetenskaplike benadering bied aan ondersoekers 'n nuwe, en verruimde, invalshoek tot die Nuwe Testament deurdat dit hulle in staat stel om alle relevante modelle en data wat betrekking het op sosiale interaksie en sosiale sisteme in hul navorsing aan te wend. Hierdie benadering hou 'n aantal belangrike voordele in, te wete:

- Dit bied toegang tot 'nuwe' dimensies van kennis, en met name dan die sosiale betekenissisteme waarbinne die Nuwe-Testamentiese tekste, as deel van die kommunikasieprosesse tussen die eerste-eeuse Christene, gefunksioneer het. Uiteraard bied die sosiaal-wetenskaplike benadering nie 'n direkte roete tot hierdie kennis nie. Dit bied hoogstens konstruksies van die sosiale sisteme waarbinne die taaluitinge wat ons in die bladsye van die Nuwe Testament aantref, waarskynlik kon gefigureer het.

- Dit stel nuwe navorsingsobjekte daar. Aspekte soos die sosiale lokalisering van gemeenskappe, rituele, grense tussen binne- en buitestaanders, sosiale ideologieë en die waardesisteme van die Mediterreense wêreld, is maar enkele van die temas wat die sosiale wetenskappe onder die aandag van Nuwe-Testamentici gebring het.

- Dit bied nuwe invalshoeke met betrekking tot bestaande navorsingsprojekte. Neyrey het byvoorbeeld in sy werk op die Johannesevangelie (vgl afd 2.2) aangetoon hoe 'tradisioneel teologiese kwessies' soos die Christologie ook vanuit ' $n$ antropologiese perspektief benader kan word en 'n nuwe betekenis verkry as dit vanuit die ideologie van die gemeenskap in wie se diens dit oorspronklik gestaan het, beskou word (vgl ook Craffert 1989:336). Sogenaamde agtergrondstudies tot die Nuwe Testament kan ook grootliks baatvind by ' $n$ sosiaal-wetenskaplike benadering, aangesien sake soos mensebeskouinge, opvattinge oor sosiale instellings soos die politiek, ekonomie en die familie, die rol van godsdiens, ensovoorts, in 'n nuwe lig gesien kan word indien dit vanuit 'n sosiaal-wetenskaplike oogpunt benader word.

Die sosiaal-wetenskaplike benadering het nie ten doel om die tradisionele metodes van eksegese te vervang nie, maar om hulle eerder aan te vul (vgl bv Elliott 1981:78; Neyrey 1988:210). Ooreenkomstig die vrae wat aan die Nuwe-Testamentiese tekste gestel word, beskou die sosiaal-wetenskaplike benadering hierdie tekste telkens aan die hand van ' $n$ aantal modelle, teorieë en voorveronderstellings wat betrekking het op hulle sosiale kontekste en wat uiteraard verskil van dié waarmee voorstanders van veral die historiese-kritiek dieselfde tekste benader. (Laasgenoemde benadering fokus grootliks op die geneties-historiese kontekste van die 
tekste.) Dit beteken egter nie dat genoemde metodes nou diametraal teenoor mekaar te staan hoef te kom, of met mekaar moet kompeteer oor welke paradigma die beste sleutel ter ontsluiting van die verlede gevind het nie. (Vergelyk in dié verband veral Moxnes 1988 en Neyrey 1988a wat daarin slaag om hierdie modelle effektief met mekaar te kombineer.) Uiteraard kan geen model 'n teks ooit uitput of finaal verklaar nie.

'n Punt van kritiek wat dikwels teen die sosiaal-wetenskaplike benadering geopper word, is juis gerig teen die eksplisiete gebruikmaking van modelle hierbinne (vgl bv Rodd, in Gill 1987:235-6), wat onder andere aanleiding sou kon gee tot 'anachronisme' en 'reduksionisme'; dit wil sê, tot die volledige oorplasing van die Nuwe Testament op die skaal van die sosiale wetenskappe, met 'n gepaardgaande verskraling van die eiesoortigheid daarvan. In antwoord hierop moet eerstens beklemtoon word dat alle navorsers, selfs ook die voorstanders van die histories-kritiese werkwyse, van bepaalde modelle en hipoteses, implisiet of eksplisiet, gebruik maak. Anachronisme en etnosentrisme is daarom ' $n$ voortdurende gevaar waarmee alle Nuwe-Testamentici in hul omgang met hierdie dokumente rekening moet hou. Trouens, 'n belangrike bydrae van die kant van die kultuur-antropologiese benadering is juis dat dit die lesers van die Nuwe Testament des te meer sensitief wil stem vir die groot kulturele en sosiale kloof tussen hierdie tekste en die huidige situasie waarbinne dit uitgelê word. Voorstanders van hierdie benadering wys daarop dat juis die histories-kritiese metode dikwels op etnosentriese wyse met die Nuwe Testament omgaan. In die woorde van Malina (1986b:116): ' ...the historicalcritical method has yet to address the question of the meaning of social realities in some objectively verifiable way, that is in a way that might account for and filter out the ethnocentric bias of the interpreter.' Die voordeel van 'n gebruikmaking van modelle binne die sosiaal-wetenskaplike benadering is trouens: '...dat daar nou doelbewus gefokus word op die metode en die wyse van rekonstruksie van die konteks van die Bybel, asook op 'n gesistematiseerde aanbieding van gegewens oor die konteks van die Bybel. Daardeur word navorsers in staat gestel om mekaar se werk te kontroleer en kan die ergste wanopvattings ten minste uitgewys word' (De Villiers 1988:5).

Tweedens moet daarop gewys word dat die sosiaal-wetenskaplike benadering homself nie aanbied as die finale antwoord met betrekking tot die Nuwe-Testamentiese ondersoek nie. Dit pretendeer ook nie om alle dimensies rakende die menslike eksistensie, soos wat daarna in die bladsye van die Nuwe Testament verwys word, aan te spreek nie. Dit is byvoorbeeld nie die taak van die sosiaalwetenskaplike metode om waarde-oordele oor die geloofsopvattinge van die eersteeeuse Christene uit te spreek nie. Indien hierdie werkswyse dan ooit die aanspraak 
sou maak dat sy konstruksies van die sosiale kontekste waarbinne bepaalde norme en gebruike in die vroeë kerk gefunksioneer het, die enigste 'korrekte' interpretasie hiervan sou wees, of dat alle vorme van gedrag in die Nuwe Testament slegs tot sosiale faktore herlei moet word, of uitsluitlik in terme hiervan verstaan behoort te word, sou dit ongetwyfeld 'reduksionisties' van aard wees en grootliks sy geldigheid binne die veld van die Nuwe-Testamentiese ondersoek verloor. As dit aan die ander kant egter op gekontroleerde wyse aangewend word, kan dit, soos reeds gesê, heelwat nuwe perspektiewe met betrekking tot ons kennis van die Nuwe Testament open.

Die sosiaal-wetenskaplike benadering bied inderdaad aan ons 'n verruimde en uiters opwindende invalshoek tot die Nuwe Testament. Veral binne die SuidAfrikaanse konteks, waar hierdie benadering in 'n groot mate deur NuweTestamentici afgeskeep is, behoort ons deeglik kennis te neem van die resultate van sosiaal-wetenskaplike ondersoeke, en die verdere moontlikhede wat dit bied, daadwerklik te ontgin.

\section{Literatuurverwysings}

Atwood, D J \& Flowers, R B 1983 . Early Christianity as a cult movement. Encounter 44, 245-261.

Botha, J 1989. Sosio-historiese en sosiologiese interpretasie van die Nuwe Testament. Koers 54, 480-508.

Craffert, P F 1989. The origins of ressurection faith: The challenge of a socialscientific approach. Neotestamentica 23, 331-348.

De Villiers, P G R 1988. Inleiding: Bybel, kerk en konteks, in Breytenbach, C (red), Kerk in konteks: Die uroeë Christendom in sosiale verband, 1-10. Pretoria: NG Kerkboekhandel.

Domeris, W R 1988. Social scientific study of the early Christian churches: New paradigms and old questions, in Mouton, J, van Aarde, A G \& Vorster, W S (eds), Paradigms and progress in Theology, 378-393. Pretoria: HSRC.

Dudley, C S \& Hilgert, E 1987. New Testament tensions and the contemporary church. Philadelphia: Fortress.

Elliott, J H 1981. A home for the homeless: A sociological exegesis of 1 Peter, its situation and strategy. London: SCM.

-.- 1986. Social-scientific criticism of the New Testament: More on methods and models. Semeia 35, 1-33.

Funk, A 1981. Status und Rollen in den Paulusbriefen: Eine inhaltsanalytische Untersuchung zur Religionssoziologie. München: Tyrolia. 
Gager, J H 1975. Kingdom and community: The social world of early Christianity. New York: Prentice Hall.

--- 1979. Social description and sociological explanation in the study of early Christianity: A review essay. RSR 5, 174-180.

Gallagher, E V 1984. The social world of saint Paul. Religion 14, 91-99.

Gill, R 1987. Theology and sociology: A reader. London: Chapman.

Hollenbach, $P$ 1987. Defining rich and poor using social sciences, in Richards, K H (ed), SBL: 1987 Seminar Papers, 50-63. Atlanta: Scholars Press.

Holmberg, B 1980. Paul and power: The structure of authority in the primitive church as reflected in the Pauline epistles. Philadelphia: Fortress.

Joubert, S J 1988. Die Judasbrief: 'n Simboliese universum in die gedrang. HTS 44, 613-635.

--. 1990. Language, ideology and the social context in the letter of Jude. Neotestamentica 24.

Judge, E A 1960. The social patterns of Christian groups in the first century. London: Tyndale.

Kee, H C 1980. Christian origins in sociological perspective: Methods and resources. Philadelphia: Westminster.

--- 1989. Knowing the truth: A Sociological approach to New Testament Interpretation. Minneapolis: Fortress.

Kyrtata, D J 1987. The social structure of the early Christian communities. London: Verso.

Louw, J P (ed) 1986. Sosiolinguistics and communication. London: UBS.

Malina, B J 1981. The New Testament world: Insights from cultural anthropology. Atlanta: John Knox.

--- 1983. Why interpret the Bible with the social-sciences? American Baptist Quarterly 2, 119-133.

--- 1984. Jesus as charismatic leader? BTB 14, 55-62.

--- 1986a. Religion in the world of Paul: A preliminary sketch. BTB 16, 92-101.

--- 1986b. Christian origins and cultural anthropology: Practical models for Biblical interpretation. Atlanta: John Knox.

--- 1987. Wealth and poverty in the New Testament and its world. Interp. 41, 354367.

--- 1988. A conflict approach to mark 7. Foundation \& Facets Forum 4, 3-30.

--- 1989a. First century Mediterranean persons. Unpublished paper delivered at Catholic Biblical Assosiation Meeting (1989).

.-- 1989b. Dealing with Biblical (Mediterranean) Characters: A guide for US consumers. BTB 19, 127-141. 
Malina, B J \& Neyrey, J H 1988. Calling Jesus names: The social value of labels in Matthew. Sonoma: Polebridge Press.

Mayer, A 1983. Der zensiente Jesus: Soziologie des Neuen Testaments. 2. Aufl. Olten: Walter.

Meeks, W A 1972. The man from heaven in Johanine sectarianism. JBL 91, 44-72.

--- 1983. The first urban Christians: The social world of the apostle Paul. New Haven: Yale University Press.

--- 1986. The moral world of the first Christians. Philadelphia: Westminster.

Moxnes, $\mathrm{H}$ 1988a. The economy of the kingdom: Social conflict and economic relations in Luke's gospel. Philadelphia: Fortress.

--- 1988b. Honour and righteousness in Romans. JSNT 32, 61-78.

Neyrey, J H 1988a. An ideology of revolt: John's Christology in social-science perspective. Philadelphia: Fortress.

--- 1988b. A symbolic approach to Mark 7. Foundation \& Facets Fonum 4, 63-91.

Osiek, C 1984. What are they saying about the social context of the New Testament? New York: Paulist Press.

Pilch, J J 1985. Healing in Mark: A social science analysis. BTB 15, 142-150.

--- 1986. The health care system in Matthew: A social science analysis. BTB 16, 102-106.

--- 1988a. Understanding Biblical healing: Selecting the appropriate model. BTB $18,60-66$.

--- 1988b. A structural functional approach to Mark 7. Foundations \& Facets Forum 4, 31-62.

--- 1989. Reading Matthew anthropologically: Healing in cultural perspective. Listening 24, 278-289.

Remus, H E 1982. Sociology of knowledge and the study of early Christianity. SR 11, 45-56.

Rohrbaugh, R L 1987. 'Social location of thought' as a heuristic construct in New Testament study. JSNT 30, 103-119.

Rowland, C 1985. Reading the New Testament sociologically: An introduction. Theology 88, 358-364.

Schmeller, T 1989. Sociologisch orientierte Exegese des Neuen Testaments. $B K$ 44, 103-110.

Scoggs, $R$ 1975. The earliest Christian communities as sectarian movement, in Neusner, J (ed), Christianity, Judaism and other Greco-Roman cults, Volume 2, 1-23. Leiden: Brill.

--- 1980. The sociological interpretation of the New Testament: The present state of research. NTS 26, 164-179. 
Smith, R H 1980. Were the early Christians middle-class? A sociological analysis of the New Testament. Currents in Theology and Mission 7, 260-276.

Stambaugh, J E \& Balch D L 1986. The New Testament in its social environment. Philadelphia: Westminster.

Stark, R 1986. The class basis of early Christianity: Inferences from a sociological model. $S A$ 47, 216-225.

Stegemann, W 1984. The Gospel and the poor, transl by D Elliott. Philadelphia: Fortress.

Theissen, G 1977. Soziologie der Jesusbeweging. München: Kaiser.

-.- 1982. The social setting of Pauline Christianity: Essays on Corinth, edited and translated by J H Schuetz. Philadelphia: Fortress.

-.- 1989. Jesusbewegung als charismatische Wertrevolution. NTS 35, 343-360.

Turner, J H 1982. The structure of sociological theory. 3rd ed. Homewood: Dorsey.

Van Aarde, A G 1988. Jesus en die sosiaal-veragtes. HTS 44, 829-846.

White, L J 1986. Grid and group in Matthew's community: The righteousness/ honor code in the sermon on the mount. Semeia 35, 61-90.

White, L M 1986. Sociological analysis of early Christian groups: A social historian's response. $S A$ 47, 249-66.

--- 1988. Shifting sectarian boundaries in early Christianity. BJRL 7-24. 